\title{
Abstract withdrawn
}

From International Conference for Healthcare and Medical Students 2011

Dublin, Ireland. 4-5 November 2011

Published: 9 July 2012

doi:10.1186/1753-6561-6-S4-013

Cite this article as: : Abstract withdrawn. BMC Proceedings 2012 6(Suppl 4):013.

Submit your next manuscript to BioMed Central and take full advantage of:

- Convenient online submission

- Thorough peer review

- No space constraints or color figure charges

- Immediate publication on acceptance

- Inclusion in PubMed, CAS, Scopus and Google Scholar

- Research which is freely available for redistribution

Submit your manuscript at www.biomedcentral.com/submit 